\title{
O RESPEITO A AUTONOMIA DA VONTADE DO PACIENTE COM TRANSTORNO MENTAL E DE COMPORTAMENTO
}

\author{
RESPECT FOR THE AUTONOMY OF THE WILL OF THE PATIENT
}

WITH MENTAL AND BEHAVIORAL DISORDER

Aline Naiade da Silva Alves ${ }^{1}$

\section{RESUMO}

O presente artigo busca discutir contornos acerca da autonomia da vontade das pessoas com transtornos mentais e/ou de comportamento, a fim de aplicar a ponderação para garantir uma efetiva promoção da autodeterminação delas, sem deixar de lado a efetiva proteção daqueles que demandam uma maior tutela por parte do Estado.

Palavras-chave: Estatuto da Pessoa com Deficiência; Consentimento Informado; Autonomia da Vontade; e Pessoas com Transtornos Mentais ou/e de Comportamento.

\begin{abstract}
This article seeks to discuss the autonomy of the will of people with mental and / or behavioral disorders, in order to apply the weighting to ensure an effective promotion of their self-determination, without neglecting the effective protection of those who demand greater protection. by the state.
\end{abstract}

Keywords: Statute of the Disabled Person; Informed consent; Autonomy of Will; and People with Mental or / and Behavioral Disorders.

\section{INTRODUÇÃO}

As pessoas com deficiência mental ou intelectual sempre despertaram a curiosidade e o medo das pessoas. A preocupação com os transtornos mentais e de comportamento ao longo da história não se limitava à ciência médica, em verdade, é um tema muito recorrente na religião, no direito e, sobretudo, no imaginário popular.

Ao longo da existência humana as pessoas com transtornos foram objeto de políticas públicas de caráter paternalista e assistencialista. Desse modo, no ordenamento

1 Técnica em enfermagem pelo SENAC. Graduada em Direito pela Universidade do Estado do Rio de Janeiro - UERJ. Pós-graduanda em advocacia pública em curso de especialização da Faculdade de Direito da Universidade do Estado do Rio de Janeiro - UERJ. Residente Jurídica na Defensoria Pública do Estado do Rio de Janeiro. Pesquisadora. Advogada. Endereço eletrônico: alinenaiade@ hotmail.com. 
jurídico brasileiro, desde as Ordenações Filipinas, estabeleceu-se a curadoria dos então denominados "mentecaptos" para os atos da vida civil. Posteriormente o Código Civil de 1916 consagrou a teoria das incapacidades, de modo a extirpar por completo a autodeterminação dos "loucos de todo gênero". A redação original do Código Civil de 2002 abrandou a discriminatória qualificação, todavia manteve a incapacidade absoluta para pessoas com "enfermidade ou deficiência mental", que não possuam discernimento para a prática dos atos da vida civil.

É com a internalização, com status supralegal, da Convenção sobre os Direitos das Pessoas com Deficiência e posteriormente o advento do Estatuto da Pessoa com Deficiência que o vetusto instituto das incapacidades sofreu profundas alterações. A pessoa com deficiência não mais se inclui entre o rol dos absolutamente incapazes de exercício dos direitos desde a internalização da Convenção, mas é com a Lei 13.105/2015 que essa derrogação se tornou explícita.

Com a profunda mudança de paradigma que a Convenção e o Estatuto trouxeram para o ordenamento jurídico brasileiro, sobretudo os assuntos que cercam o direito civil, restam questionamentos acerca da autonomia da vontade dos pacientes com transtornos mentais e/ou de comportamento.

No presente trabalho, propõe-se a discussão de contornos, acerca da autonomia da vontade, a fim de aplicar a ponderação para garantir uma efetiva promoção da autodeterminação das pessoas com transtornos mentais e de comportamento, sem deixar de lado a efetiva proteção daqueles que demandam uma maior tutela por parte do Estado.

\section{DA INVISIBILIDADE AO MODELO SOCIAL: MODELO DE PRESCINDÊNCIA, MODELO MÉDICO OU REABILITADOR E MODELO SOCIAL}

A cultura, o momento histórico e a sociedade são fatores fundamentais para designar as características de um determinado povo e os parâmetros que o orienta. $\mathrm{O}$ trato ofertado às pessoas com deficiência também se submete a esses fatores, o que gera diferentes tipos de tratamentos destinados a elas ao longo da história da humanidade até o advento do que se denomina como "modelo social", o qual encontra na Convenção da ONU sobre os Direitos das Pessoas com Deficiência, bem como no seu protocolo facultativo a sua maior expressão. 
O filme "300", dirigido por Zack Snyder, retrata a batalha de Termópilas, durante as Guerras Médicas entre gregos e persas, no ano de 480 A.C. - período Clássico. O filme sugere que os espartanos só foram definitivamente abatidos em razão da traição de Efialtes, um homem com má-formação e que tinha o sonho de servir ao exército espartano. Ele indicou ao exército de Xerxes uma trilha em Amôpaia, a qual serviu para uma emboscada. Tal conduta foi a forma encontrada por Elfialtes de se vingar de Esparta por ter sido vítima quando bebê da política de eugenia adotada na cidade-estado e, após sobreviver a tentativa de infanticídio, a discriminação sofrida na ocasião em que se oferecera para lutar ao lado do exército espartano contra Xerxes.

A história de Elfiates retratada no filme descreve uma conduta comum na Grécia Antiga, que também é encontrada na história de vários outros povos, em relação as crianças que nasciam com algum tipo de deficiência, trata-se do primeiro modelo de trato adotado pela sociedade, o denominado modelo de prescindência ou rejeição social. Para esse modelo as pessoas com deficiência eram prescindíveis, daí a escolha do nome, vez que não poderiam agregar à comunidade nenhum tipo de benefício. Ademais, era comum que as deficiências fossem vistas como uma forma de castigo dos deuses, ou ainda que fossem as pessoas com deficiência responsabilizadas por eventuais desgraças que recaíssem sobre a comunidade.

O modelo de prescindência, perdurou da Grécia antiga até a Idade Média, ele apresenta duas consequências distintas, em que pese partir das mesmas primícias. Desse modo, o modelo era subdividido em duas espécies, quais sejam: i) o submodelo eugênico; e ii) o submodelo de marginalização. O primeiro é o retratado na história de Elfiates, no qual imperava políticas de eugenia, tal como o infanticídio. Já o segundo foi visto predominantemente na Idade Média e consistia na segregação, vez que as pessoas com deficiência eram tidas pela sociedade como pertencentes ao mesmo grupo dos "pobres" e "marginalizados" e, portanto, excluída da vida social da comunidade. Uma característica marcante dessa época deve-se à concepção cristã-católica que imperava nesse momento histórico, a qual consistia na ideia de que a deficiência era uma situação imodificável e que deveria ser aceita com resignação. Ademais, o sistema religioso e o sistema científico possuíam o mesmo fundamento, de modo que estavam ambos submetidos à lógica teológica.

Conforme ressalta Augustina Palácios, enquanto o submodelo eugênico matava de modo direto as pessoas com deficiência, o submodelo de marginalização o fazia de modo 
indireto em razão de omissão, seja por ausência de interesse ou de recursos, ou ainda em virtude de valer-se da fé como único meio de salvação. ${ }^{2}$

Com o Renascimento avançou-se consideravelmente com o estudo da anatomia e da cirurgia, era comum os artistas da época atuarem de maneira secundária como anatomistas, tal como ocorreu com Leonardo da Vinci. Com o progresso dos estudos do corpo humano, passou-se a identificar que as deficiências tinham origem nas másformações do corpo e ao sistema científico ficava o encargo de estudar e atender essas pessoas que possuíam algum tipo de deficiência. Nos séculos XVII e XVIII passou a ser comum a internação desses indivíduos em hospitais especializados, a fim de que se pudesse estudar melhor essas anomalias, bem como proceder no fornecimento de algum tipo de tratamento. Subsistia a segregação dessas pessoas na vida social.

É no final do século XIX e início do século XX que o modelo reabilitador ganha força, nele as pessoas com deficiência deixaram de serem vistas como totalmente inúteis à comunidade, vez que a integração delas à vida em sociedade passou a ser uma possibilidade à medida que elas atravessavam um processo de "reabilitação" das suas limitações em decorrência dos avanços médicos. Acredita-se que foram duas as principais causas que impulsionaram essa mudança de paradigma, quais sejam: as guerras e os acidentes de trabalho ${ }^{3}$.

Os acidentes de trabalho têm sua origem na Revolução Industrial, são com os avanços tecnológicos que despontaram à época, sobretudo a maquinofatura, é que começaram a surgir as primeiras fábricas. Com esses novos processos de produção, iniciados na Inglaterra, surge a classe de operários, esse grupo social encontrava-se submetido a condições e de vulnerabilidade no que tange a moradia, a alimentação, a educação e, sobretudo, ao trabalho ${ }^{4}$.

Com o intuito de obter o máximo de lucro, a burguesia pagava os menores salários possíveis, de modo que davam preferência à contratação de mulheres e crianças para trabalhar em suas fábricas, vez que os salários pagos eram inferiores aqueles auferidos pelos homens, mas a jornada de trabalho era a mesma, em torno de 15 horas por dia. Os acidentes de trabalho nas fábricas começaram a se tornarem comuns (não existia nenhuma

2 PALACIOS, Augustina. El modelo social de discapacidad: orígenes, caracterización y plasmación en la Convención Internacional sobre los Derechos de las Personas con Discapacidad. Madrid: Cermi, 2008, p. 15.

3 Idem, p. 16.

4 AZEVEDO, Gislaine Campos; SERIACOPI, Reinaldo. História: volume único. São Paulo: Ática, 2005, p. 242-243. 
norma protetiva aos trabalhadores e imperava a lei da oferta e da procura), seja em razão da exaustão provocada pelas longas jornadas de trabalho ou pela falta de equipamentos de proteção individual. Fato é que aumentou consideravelmente o número de pessoas que não nasceram deficientes, mas se encontravam com algum tipo de "incapacidade".

A primeira Guerra Mundial deixou um saldo de 8 milhões de mortos e 20 milhões de inválidos ${ }^{5}$, a sociedade precisava receber esses sobreviventes mutilados que tinham perdido órgãos, sentidos e, até mesmo, a própria sanidade em razão dos horrores vivenciados durante a guerra.

À vista disto, passou a surgir diversas políticas públicas com o intuito de compensar em alguma medida as perdas que essas pessoas tiveram, em especial para os mutilados de guerra. Só na década de 1970 que essas políticas assistencialistas se estenderam para todas as pessoas com deficiência, sem discriminar qual a origem. Procurava-se "normalizar" as pessoas e adaptá-las à vida em sociedade.

Para Augustina Palácios:

De esto modo, las personas com discapacidad recibían benefícios de los servicios sociales porque la discapacidad se veia exclusivamente como um problema individual de la persona, quien no era capaz de enfrentarse a la sociedade.

(...)

El modelo rehabilitador se considera a la discapacidad exclusivamente como um problema de la persona, diretamente ocasionado por uma enfermidade, acidente, o condición de la salud, que requiere de cuidados médicos prestados por profesionales em forma de tratamento indivicual. Em consequência, el tratamento de la discapacidad se encuentra encaminhado a conseguir la cura, o una mejor adaptación de la persona, o um cambio em su conducta. De este modo, desde em punto de vista jurídico, la discapacidad es abordada exclusivamente dentro de la legislación de la assistência y seguridade social, o como parte de ciertas cuestones del derecho civil relacionadas com la incapacitación y la tutela ${ }^{6}$. (Grifo nosso)

O modelo médico ou reabilitador parte da permissa de que é necessário tutelar as pessoas com deficiência e, para tanto, o ordenamento jurídico necessita de normas que propiciem assistência e proteção para elas. No que tange as pessoas com transtornos mentais e de comportamento, a pretensa proteção intensifica-se vez que se retira o autogoverno e a autodeterminação sob a justificativa de que elas não conseguem se normalizar e nem se adaptar à vida em sociedade.

Idem, p. 379.

6 PALACIOS, Augustina. El modelo social de discapacidad: orígenes, caracterización y plasmación en la Convención Internacional sobre los Derechos de las Personas con Discapacidad. Op. cit., p. 17. 
Entre o final da década de 60 e início da década de 70 surge um terceiro modelo que difere dos anteriores, pois entende que a origem da deficiência não está na religião ou na ciência, em verdade, reside na sociedade. Afirma Augustina Palácios que:

Según los defensores de este modelo, no son las limitaciones individuales las raíces del fenómeno, sino las limitaciones de la sociedad para prestar servicios apropriados y para asegurar adecuadamente que las necesidades de las personas com discapacidad sean tenidas en cuenem dentro de la organizacion social $^{7}$.

Começou a surgir grupos na Inglaterra e nos Estados Unidos da América, protagonizados pelas pessoas com deficiência, com a finalidade de extirpar a concepção de que as pessoas com deficiência seriam cidadãos de segunda classe e que representavam um problema para o Estado.

Nos Estado Unidos, sob a ótica liberal, o movimento das pessoas com deficiência foi impulsionado pela luta pelos direitos civil das pessoas negras. Esse movimento intitulado por Garben Dejong ${ }^{8}$ de "vida independente", utilizou-se dos pilares que envolviam a sociedade americana, quais sejam, capitalismo de mercado, independência, liberdade política e econômica para desenvolver-se. Ele objetivava promover a autonomia e a independência das pessoas com deficiência e, para tanto, caberia a elas definir as metodologias, os objetivos e a direção dos programas governamentais que a elas eram endereçados, o que representou uma mudança profunda aos tradicionais métodos utilizados até então 9 .

Já na Inglaterra, sob a guarida de um sistema que priorizava o Estado de bem-estar social, o movimento teve por escopo alcançar mudanças nas políticas sociais, bem como na legislação de direitos humanos. A principal bandeira levantada por esse grupo envolve a desconstrução da ideia de que as pessoas com deficiência pertencem a um grupo indefeso que necessita de proteção. Pleiteava-se, assim como nos EUA, o protagonismo de sua própria história por meio do direito de definir suas necessidades e os serviços prioritários a elas destinados ${ }^{10}$.

7 Idem, p. 19.

8 DEJONG, G. The movement for independent living: origins, ideology and implications for disability research, Michigan State University Press: East Lansing, 1979; SHAPIRO, J. No pity. People with disabilities for ging a new civil right movement, Times Books, New York: Random House, $1994 \mathrm{y}$ GARCIA ALONSO, J. V. (coord.), El movimiento de vida independiente: Experiencias Internacionales, Madrid: Fundación Luis Vives, 2003.

9 PALACIOS, Augustina; BARIFFI, Francisco. La discapacidad como uma cuestión de derechos humanos: uma aproximación a la Convención iternacional sobre los derechos de las personas com discapacidad. Telefónica y Cermi. Madrid: Cinca, 2007, 107-108.

10 PALACIOS, Augustina. El modelo social de discapacidad: orígenes, caracterización y plasmación en la Convención Internacional sobre los Derechos de las Personas con Discapacidad. Op. cit., p. 21. 
Os dois modelos anteriormente expostos possuem pontos em comuns, todavia foram concebidos sob prismas (origem e justificativa) distintos. $\mathrm{O}$ principal legado deixado por eles, e que influenciou o modelo social nos moldes instituído pela Convenção da ONU dos direitos das pessoas com deficiência de 2006, é a concepção de que a deficiência é um fenômeno complexo e não um problema médico e individual. Nas palavras de Augustina Palacios: sitúa al individuo em el centro de todas las decisiones que le afecten y sitúa el centro del problema fuera de la persona - em la sociedade - ${ }^{11}$.

Assim sendo, pode-se concluir que o modelo social visa alcançar um ideal social de inclusão em que a pessoa com deficiência possa desfrutar uma igualdade de oportunidades em todas as esferas de sua vida. Para tanto, busca-se extirpar legislações discriminatórias, bem como promover políticas públicas, legislativas e sociais inclusivas para que essas pessoas possam alcançar independência, liberdade, autodeterminação e autossuficiência, levando em consideração as limitações individuais apresentadas por cada uma delas. Conforme leciona Heloisa Helena Barboza e Vitor Almeida:

\footnotetext{
A deficiência é um problema social, que exige intervenções na sociedade; as causas da deficiência não são religiosas, nem somente médicas - são predominantemente sociais. As raízes dos problemas não são as restrições ou faltas (diferenças) individuais, mas as limitações ou impedimentos impostos pela sociedade que não tem os meios/serviços/instrumentos adequados para que essas pessoas sejam consideradas incluídas na sociedade ${ }^{12}$.
}

As pessoas com deficiência possuem igual valor e dignidade, não se está diante de situações que devem ser toleradas ou que sejam passíveis de compadecimento, em verdade, estar-se-á diante da própria diversidade humana, a qual caracteriza a sociedade moderna.

\section{O TRATAMENTO CONFERIDO A PESSOA COM TRANSTORNO MENTAL E/OU DE COMPORTAMENTO NO ORDENAMENTO JURÍDICO BRASILEIRO}

3.1 A INCAPACIDADE NA LEGISLAÇÃO BRASILEIRA

11 Idem, p. 23.

12 BARBOZA, Heloisa Helena, ALMEIDA JUNIOR, Vitor de Azevedo. Reconhecimento, inclusão e autonomia da pessoa com deficiência: novos rumos na proteção dos vulneráveis. In: BARBOZA, Heloisa Helena; MENDONÇA, Bruna Lima de; ALMEIDA JUNIOR, Vitor de Azevedo (Coords.). O Código Civil e o Estatuto da Pessoa com Deficiência. Rio de Janeiro: Editora processo, 2017, p. 130. 
A pretensa tutela às pessoas com transtornos mentais e de comportamento não é um tema novo no direito brasileiro e nem surgiu com o Código Civil de 1916. Desde as Ordenações Filipinas, promulgadas no ano de 1603 pelo rei de Portugal Felipe I, procurou-se retirar a autodeterminação dessas pessoas, seja na esfera personalíssima ou no âmbito patrimonial. O Livro IV, Título 103 das Ordenações era dedicado à regulamentação “dos curadores, que dão aos pródigos e mentecaptos”, ele previa que:

\begin{abstract}
Porque além dos Curadores, que hão de ser dados aos menores de vinte cinco anos, se devem também dar Curadores aos Desasisados e desmemoriados, e aos Prodigos, que mal gastarem suas fazendas.

Mandamos que tanto que o Juiz dos Orfãos souber que em sua jurisdicção há algum Sandeu, que por causa de sua sandice possa fazer mal, ou dano algum na pessoa, ou fazenda, o entregue a seu pai, se o tiver, o lhe mande de nossa parte, que dahi em diante ponha nelle boa guarda, assi na pessoa, como na fazenda; e se cumprir o faça apriozar, em maneira que não possa fazer mal a outrem.

(...) E os bens que o Sandeu tiver, serão entregues ao dito se pai per inventário feito pelo Serivão dos Orfãos, e o Juiz ordenará certa cousa ao dito pai per que o haja de manter. ${ }^{13}$ (Grifo nosso)
\end{abstract}

Depreende-se do texto exposto que a principal preocupação das Ordenações Filipinas dizia respeito à propriedade ou ao eventual dano que os mentecaptos poderiam gerar a terceiros. O controle estatal acerca da determinação da incapacidade era tão expressivo, que chegava ao ponto de o texto legal determinar que o juiz deveria agir de ofício para efetivar uma pretensa tutela dos denominados sandeus.

O viés patrimonialista era tamanho que a própria pessoa era vista como uma "coisa" pela Ordenação, à medida que o curador teria o direito de administrar "a pessoa do Sandeu"14. Os bens das pessoas com transtornos seriam entregues ao pai, ao filho ou à esposa, para esta por exigia-se que vivesse honestamente, que possuísse entendimento e discrição, vide:

E esta Curadoria administrará o pai ou a mulher, em quanto o filho ou marido durar na sandice. E tornando a seu perfeito siso e entendimento, ser-lhe-hão tornados e restituídos seus bens com toda livre administração deles, como a tinha, antes que perdesse o entendimento.

(...)

Porém, se sua mulher viver honestamente, e tiver entendimento e discrição, e quiser tomar carrego se seu marido, ser-lhe-ão entregues todos seus bens, sem ser obrigada fazer inventário ${ }^{15}$.

13 Ordenações Filipinas, vol. 4. Edição de Cândido Mendes de Almeida, Rio de Janeiro de 1870, p. 1004/1005. Disponível em: <http://www1.ci.uc.pt/ihti/proj/filipinas/14p1004.htm>. Consulta em: 15 de ago. 2017.

14 E tanto que torna à sandice, logo seu pai, ou mulher usará da Curadoria, e regerá e administrará a pessoa e fazenda dele, como dantes.

15 Idem, p. 1005/1006. 
Junto com a independência brasileira veio ordem dada para a elaboração de um Código Civil nacional, a Constituição de 1824, art. 179, XVIII determinava que: organizar-se-á quanto antes um Código Civil, e Criminal, fundado nas sólidas bases da Justiça, e Equidade. Todavia, após vários projetos ${ }^{16}$, apenas em 1917 foi promulgado o primeiro Código Civil do Brasil.

O Código pensado por Clóvis de Beviláqua, tardio em relação à época que buscava representar, trazia a capacidade de agir como regra, sendo excetuada em razão da idade ou do estado de saúde. Em seu artigo $5^{\mathrm{o17}}$, da parte geral, o Código tratou dos portadores de transtornos mentais e/ ou de comportamento como absolutamente incapazes e utilizouse da, no mínimo, inadequada expressão "loucos de todo gênero" para a eles se referir. A impropriedade do uso de tal expressão foi duramente criticada por autores como Washington de Barros Monteiro ${ }^{18}$.

A utilização da expressão "loucos de todo gênero" era tradicionalmente usada pelos juristas à época e tinha por escopo englobar todas as pessoas que apresentassem qualquer espécie de desequilíbrio de suas funções cerebrais. Desse modo, deixava-se de lado a complexidade que envolve todas as doenças mentais e colocava-se em igual patamar um indivíduo que apresentava uma completa alienação mental, ao ponto de não se reconhecer como um ser humano e nem ter a capacidade de entender o mundo ao seu redor, e os que possuíam pequenos distúrbios comportamentais.

Com o advento do Código Civil de 2002, agora já na vigência da Constituição de 1988, a situação dos que possuem transtornos mentais e de comportamento sofreu uma singela modificação, vez que o Código procurou delimitar melhor a incapacidade absoluta e a relativa. Substitui-se a fatídica expressão "loucos de todo gênero" por "enfermidade

16 Diversos projetos de Código Civil foram elaborados, dentre os quais destaca-se o Esboço de Código Civil apresentado em 1862 por Augusto Teixeira de Freitas. Ele sofreu diversas críticas quando levado a uma comissão de juristas escolhida pelo ministro da Justiça, o conselheiro Martiniano de Alencar. Argumentou-se no sentido de que ele seria inaplicável à realidade social brasileira, à medida que em determinados aspectos não levava em consideração as peculiaridades que permeava os costumes consolidados durante a formação da sociedade brasileira à época. Se para o Brasil chegou-se à conclusão de que ele era inadequado, na Argentina e no Uruguai o desfecho foi diferente, pois o trabalho de Augusto Teixeira de Freitas serviu de orientação para os códigos civis de ambos os países.

17 Art. 5. São absolutamente incapazes de exercer pessoalmente os atos da vida civil:

I. Os menores de dezesseis anos.

II. Os loucos de todo o gênero.

III. Os surdos-mudos, que não puderem exprimir a sua vontade.

IV. Os ausentes, declarados tais por ato do juiz.

18 “(...) preferível teria sido o uso da palavra alienados, esta sim, compreensiva de todos os casos de insanidade mental, permanente e duradoura, caracterizada por graves alterações das faculdades psíquicas". MONTEIRO, Washington de Barros. Curso de Direito Civil: Parte Geral. 19. ed. São Paulo: Saraiva, - -, p. 61. 
mental" e o "necessário discernimento", artigo $3^{\circ}$ do Código Civil de 2002, passou a ser o parâmetro para enquadrar o indivíduo como absolutamente ou relativamente incapaz.

Ocorre que os preceitos estabelecidos pelo legislador são expressões com conteúdo aberto que podem englobar uma série de situações e peculiaridade. Desse modo tem-se que é trabalho da doutrina e da jurisprudência traçar esses parâmetros, a fim de adequar a legislação da melhor forma possível aos casos concretos que se apresentem nas situações da vida.

Em que pese as transformações trazidas pelo Código Civil de 2002, as normativas que tratam das pessoas com deficiência ainda continuaram aquém daquilo que a Carta de 1988 estabeleceu. Conforme leciona Nelson Rosenvald ${ }^{19}$, mostra-se incompatível com o sistema constitucional, que tem por fundamento a Dignidade da Pessoa Humana (art. $1^{\circ}$, III, CF), normas que estabelecem uma eterna incapacidade absoluta, que o autor chama de categorias de "não pessoas", em razão do estado de saúde, sem que para as mesmas seja ofertado um projeto terapêutico individualizado que leve em conta as necessidades de cada indivíduo.

Desse modo, conclui-se que, antes mesmo da internalização da Convenção sobre os Direitos das Pessoas com Deficiência e posteriormente o advento do Estatuto da Pessoa com Deficiência, a legislação infraconstitucional que estabelecia a incapacidade absoluta era inconstitucional, vez que impedia que as pessoas com transtornos mentais ou de comportamento pudessem desenvolver todos os aspectos de sua personalidade, ou seja, seu projeto de vida o que, em última análise, caracterizava uma profunda violação a dignidade humana dessas pessoas.

\subsection{O ADVENTO DO ESTATUTO DA PESSOA COM DEFICIÊNCIA E SEU REFLEXO NO INSTITUTO DA INCAPACIDADE}

O regime das incapacidades ao ser instituído almejou a proteção dos indivíduos que, em alguma medida, possuíssem limitações no exercício de sua autonomia. A clássica teoria das incapacidades foi concebida sob a guarida do patrimonialismo e do individualismo, a fim de garantir a proteção do patrimônio do então entendido como incapaz, conforme visto no tópico anterior. Ocorre que essa pretensa tutela não se coaduna

19 ROSENVALD, Nelson. A “caixa de pandora" da incapacidade absoluta. Disponível em: <https://www.nelsonrosenvald.info/single-post/2017/06/06/A-\%E2\%80\%9Ccaixa-de Pandora\%E2\%80\%9D-da-incapacidade-absoluta>. Consulta em: 13 nov. 2017. 
com o centro axiológico do sistema constitucional brasileiro: a dignidade da pessoa humana.

Para Nelson Rosenvald, sob o prisma do modelo liberal, há um direito fundamental à capacidade civil $^{20}$, à medida que a Constituição Federal estabelece uma tutela promocional ao desenvolvimento da pessoa humana e, por conseguinte, uma potencialização do princípio da autonomia individual. Com a adoção pelo Brasil da Convenção sobre os direitos da pessoa com deficiência, primeiro tratado internacional de direitos humanos aprovado pelo Congresso Nacional conforme o procedimento estabelecido no $\S 3^{\circ}$, art. $5^{\circ}$ da Constituição Federal, a incapacitação civil em razão da saúde torna-se, ou pelo menos deveria, um fenômeno ainda mais limitado e o ônus argumentativo para o seu estabelecimento passaria a ser ainda maior, haja vista que o seu propósito, estipulado no artigo $1^{\mathrm{o}}$ da Convenção, é "promover, proteger e assegurar o exercício pleno e equitativo de todos os direitos humanos e liberdades fundamentais por todas as pessoas com deficiência e promover o respeito pela sua dignidade inerente".

Todavia, é apenas com a Lei Brasileira de Inclusão da Pessoa com Deficiência (Lei no 13.146/15), também conhecida como o Estatuto da Pessoa com Deficiência, que o arcaico instituto da (in)capacidade sofre uma profunda transformação. Com a finalidade de efetivar os comandos da Convenção (artigo $12^{21}$ ), o Estatuto altera o art. $3^{\circ}$ do Código Civil, pois derroga os incisos I e II, bem como estabelece uma nova redação ao caput. Em

20 ROSENVALD, Nelson. O modelo social de direitos humanos e a convenção sobre os direitos das pessoas com deficiência - o fundamento primordial da Lei $n^{\circ}$ 13.146/2015. In: MENEZES, Joyceane Bezerra de (Coord.). Direito das pessoas com deficiência psíquica e intelectual nas relações privadas: convenção sobre os direitos da pessoa com deficiência e Lei brasileira de inclusão. Rio de Janeiro: Editora processo, 2016, p. 97.

21 Artigo 12 - Reconhecimento igual perante a lei

1.Os Estados Partes reafirmam que as pessoas com deficiência têm o direito de ser reconhecidas em qualquer lugar como pessoas perante a lei.

2.Os Estados Partes reconhecerão que as pessoas com deficiência gozam de capacidade legal em igualdade de condições com as demais pessoas em todos os aspectos da vida.

3.Os Estados Partes tomarão medidas apropriadas para prover o acesso de pessoas com deficiência ao apoio que necessitarem no exercício de sua capacidade legal.

4.Os Estados Partes assegurarão que todas as medidas relativas ao exercício da capacidade legal incluam salvaguardas apropriadas e efetivas para prevenir abusos, em conformidade com o direito internacional dos direitos humanos. Essas salvaguardas assegurarão que as medidas relativas ao exercício da capacidade legal respeitem os direitos, a vontade e as preferências da pessoa, sejam isentas de conflito de interesses e de influência indevida, sejam proporcionais e apropriadas às circunstâncias da pessoa, se apliquem pelo período mais curto possível e sejam submetidas à revisão regular por uma autoridade ou órgão judiciário competente, independente e imparcial. As salvaguardas serão proporcionais ao grau em que tais medidas afetarem os direitos e interesses da pessoa.

5. Os Estados Partes, sujeitos ao disposto neste Artigo, tomarão todas as medidas apropriadas e efetivas para assegurar às pessoas com deficiência o igual direito de possuir ou herdar bens, de controlar as próprias finanças e de ter igual acesso a empréstimos bancários, hipotecas e outras formas de crédito financeiro, e assegurarão que as pessoas com deficiência não sejam arbitrariamente destituídas de seus bens. 
suma, a incapacidade absoluta para o exercício dos atos da vida civil restringiu-se aos menores de dezesseis anos. Com o intuito de deixar explícita essa nova condição que é dada as pessoas com deficiência a Lei de inclusão da pessoa com deficiência prevê em seu art. $6^{\circ}$ o seguinte:

Art. $6^{\circ} \mathrm{A}$ deficiência não afeta a plena capacidade civil da pessoa, inclusive para:

I - casar-se e constituir união estável;

II - exercer direitos sexuais e reprodutivos;

III - exercer o direito de decidir sobre o número de filhos e de ter acesso a informaç̃̃es adequadas sobre reprodução e planejamento familiar;

IV - conservar sua fertilidade, sendo vedada a esterilização compulsória;

$\mathrm{V}$ - exercer o direito à família e à convivência familiar e comunitária; e

VI - exercer o direito à guarda, à tutela, à curatela e à adoção, como adotante ou adotando, em igualdade de oportunidades com as demais pessoas.

É nesse ponto que se observa a preocupação do Estatuto em estabelecer mecanismos de promoção às situações existenciais que envolvem as pessoas com deficiência.

A incapacidade relativa subsiste para aqueles que apresentam transtornos mentais e de comportamento quando não puderem, por causa transitória ou permanente, exprimir sua vontade, nos termos da nova redação dada ao art. $4^{\circ}$ do Código Civil.

Em decorrência de tais modificação, a interdição, a priori, deixa de existir no ordenamento brasileiro, vez que a incapacidade absoluta só existe em razão da idade. Ressalta-se que há debate acerca do tema, vez que há situações, tal como a pessoa em estado de coma ou com idade mental de dois anos, que podem ser entendidas como incompatíveis com a curatela e a tomada de decisão apoiada, os regimes estabelecidos pelo Estatuto que visam abrir espaço no ordenamento para medidas mais inclusivas (art.116).

O regime da Curatela, com o advento do Estatuto, será uma medida extraordinária (art. 84) e abrangerá somente os atos de natureza patrimonial, conforme prevê o art. 85 do Estatuto, nos seguintes termos:

Art. 85. A curatela afetará tão somente os atos relacionados aos direitos de natureza patrimonial e negocial.

$\S 1^{\circ}$ A definição da curatela não alcança o direito ao próprio corpo, à sexualidade, ao matrimônio, à privacidade, à educação, à saúde, ao trabalho e ao voto.

$\S 2^{\circ}$ A curatela constitui medida extraordinária, devendo constar da sentença as razões e motivações de sua definição, preservados os interesses do curatelado.

$\S 3^{\circ}$ No caso de pessoa em situação de institucionalização, ao nomear curador, o juiz deve dar preferência a pessoa que tenha vínculo de natureza familiar, afetiva ou comunitária com o curatelado. 
O processo que define os termos da curatela levará em conta as necessidades apresentadas pelo indivíduo, desse modo ter-se-á níveis de ingerência distintos do curador na vida do curatelado, vide:

i) O curador pode se apresentar como um representante do relativamente incapaz para todo os atos jurídicos, porque este não possui qualquer condição de praticá-los, sequer em conjunto. Seria o caso de alguém que se encontra no coma ou a quem falta qualquer discernimento;

ii) $\mathrm{O}$ curador pode ser um representante para certos e específicos atos e assistente para outros, em um regime misto, quando se percebe que o curatelado tem condições de praticar alguns atos, devidamente assistidos, mas não possui qualquer possibilidade de praticar outros, como, por exemplo, os atos patrimoniais;

iii) O curador será sempre um assistente, na hipótese em que o curatelado tem condições se praticar todo e qualquer ato, dês de que devidamente acompanhado, para a sua proteção. ${ }^{22}$

O outro instituto previsto no Estatuto é a tomada de decisão apoiada (art. 114), destina-se a pessoa com deficiência que pode exprimir sua vontade. Ele consiste em um procedimento especial de jurisdição voluntária, que tem por único legitimado para sua propositura a própria pessoa com deficiência e, por conseguinte, poderá ser revogado a qualquer tempo por ela. Tem por escopo a eleição de, no mínimo, duas pessoas idôneas como apoiadores, bem como de traçar os limites para a atuação deles, que poderá englobar situações existenciais e/ou patrimoniais.

O modo que se dará esse apoio se apresentará de forma variada podendo consistir na facilitação da comunicação, na prestação de informações e esclarecimentos, no auxílio à análise dos fatores favoráveis e desfavoráveis que circundam certa decisão etc., tudo a depender do caso específico e das demandas da pessoa que precisa do apoio ${ }^{23}$. A homologação pelo juiz não reduz a capacidade civil daquele que propôs a ação, tampouco ocorrerá algum tipo de redução de sua autonomia. É importante ressaltar que a necessidade de apoio não se confunde com incapacidade.

Conforme exposto acima, o Estatuto da pessoa com deficiência procurou dar efetivação à Convenção interamericana dos direitos das pessoas com deficiência, bem como objetivou proporcionar maior autonomia à pessoa com deficiência e com isso retirou do ordenamento jurídico a regra que previa a incapacidade absoluta em razão do

22 FARIAS, Cristiano Chaves de; CUNHA, Rogério Sanches; PINTO, Ronaldo Batista. Estatuto da pessoa com deficiência comentado artigo por artigo. 2. ed. Salvador: JusPodivm, 2016, p. 242.

23 MENEZES, Joyciane Bezerra de Menezes. O novo instituto da tomada de decisão apoiada: instrumento de apoio ao exercício da capacidade civil da pessoa com deficiência instituído pelo Estatuto da pessoa com deficiência - Lei brasileira de inclusão (Lei no 13.146/2015). In: MENEZES, Joyciane Bezerra de Menezes (Coord.). Direito das pessoas com deficiência psíquica e intelectual nas relações privadas: convenção sobre os direitos da pessoa com deficiência e Lei brasileira de inclusão. Rio de Janeiro: Editora processo, 2016, p. 620. 
estado de saúde. Mostra-se evidente a preocupação do Estatuto com a autonomia das pessoas com deficiência, sobretudo no que tange as relações existenciais. De modo explícito estabelece que as pessoas com deficiência podem - e devem - se autodeterminar e é nesse ponto que surge a indagação que deu origem ao presente trabalho: pode, ainda que não consigam exprimir sua vontade, a pessoa com transtornos mentais e de comportamento determinar o plano terapêutico ao qual será submetida?

\section{AUTONOMIA DA VONTADE DO PACIENTE}

\subsection{UM BREVE HISTÓRICO DA RELAÇÃO MÉDICO-PACIENTE}

Nos primórdios da humanidade o médico era considerado um ser dotado de poderes curativos sobrenaturais, era ele o mago, o sacerdote, o xamã ou, como podemos verificar na cultura indígena brasileira, o Pajé. Ele ocupava lugar de destaque na organização social a qual pertencia, de modo que prevalecia a ideia de que eram seres dotados de superioridade possuindo assim uma posição de privilégio junto aos deuses. Assim sendo, seus diagnósticos e métodos utilizados não eram questionados, conforme aponta Júlio Cézar Meirelles Gomes:

\footnotetext{
O erro médico na visão do leigo é a antítese da magia inerente aos deuses, ou de quem ungido do poder divino dispões do poder de cura, isto é, o poder que remite o erro natural. Haja vista que o conceito de doença na Medicina antiga era exatamente a versão orgânica da culpa ou expressão material do pecado. Por tradição, deduz-se que aquele que cura absolve a culpa, desfaz o erro de origem semelhante. Por isso, soa como despropósito que o médico possa ele também errar, sobretudo no exercício da cura! ${ }^{24}$
}

Nessa perspectiva, desenvolve-se a ideia, a qual prevaleceu por séculos, de que o paciente é o sujeito passivo da relação e que se conforma com os procedimentos adotados pelo médico, manifestados por meio do plano terapêutico. Tanto é, que o significado da palavra "paciente" remete à ideia de indivíduo com que tem a virtude da paciência; conformado, resignado, que sabe esperar com calma e tranquilidade ${ }^{25}$. O que se verifica,

24 GOMES, Júlio Cezar Meirelles. Erro médico: reflexões. Disponível em: <http://revistabioetica.cfm.org.br/indez.ph/revista_bioetica/article/viewArticle/459>. Acesso em 10 de mai. 2019.

25 Dicionário Michaelis. Disponível em: < http://michaelis.uol.com.br/busca?id=okKKG>. Acesso em 11 de mai. 2019. 
sobretudo a partir do séc. XV, é uma subvaloração do paciente, o qual era um objeto da atuação médico, tratava-se a enfermidade e não do paciente ${ }^{26}$.

Conforme visto no capítulo anterior, as Revoluções Burguesas trouxeram grande mudança no paradigma da vontade, todavia, essas modificações não alcançaram a relação médico-paciente, de modo que o respeito a autonomia da vontade não chegou na seara médica. Em verdade, as mudanças vindas a partir do séc. XVIII, com o advento do iluminismo, trouxeram impactos para a medicina apenas em relação a sua crença, haja vista que o homem racional passou a considerar verdade absoluta aquilo que poderia ser comprovado e chancelado pela ciência.

Era preciso submeter os tratamentos médicos ao método cartesiano, decompô-los em categorias simples, para ao final chegar à verdade absoluta racial, a única que poderia ser aceita. Esse novo paradigma racional, conforme se verá mais a frente, foi o responsável por dar o primeiro passo para que a medicina adentrasse a seara do parto, o qual foi, desde o início da humanidade, um acontecimento familiar protagonizado por mulheres.

Sucede que no decorrer do século XX a área das ciências biomédicas sofreu grande transformação, haja vista as inovações tecnológicas alcançadas nesse período. Tais mudanças acompanharam o crescimento da importância dos direitos fundamentais, assim como o protagonismo que o valor da dignidade humana alcançou. A medicina não ficou indiferente, de modo que a Bioética surge como uma guia que orienta uma nova visão da relação médico-paciente. Gustavo Borges afirma que:

A relação médico-paciente, nesse sentido, tem passado por profundas transformações nos últimos anos. Evoluiu a partir de uma postura paternalista e centrada no conhecimento e nas decisões do médico para uma relação interpessoal e de diálogo, que aproxima o paciente do galeno. ${ }^{27}$

Os valores que se encontram embutidos no valor dignidade da pessoa humana impõe que reflexões necessárias a relação médico-paciente. Isso porque, o ser humano visto como um fim em si mesmo, jamais um meio ou instrumento, e que possui o direito de ser o protagonista de sua própria vida, não se compatibiliza com vínculo tradicional de submissão do paciente a todas as decisões do seu médico.

26 BORGES, Gustavo. Responsabilidade civil por ausência de consentimento informado no atendimento médico: panorama jurisprudencial do STJ. Revista de direito privado. Vol. 64/2015, Out - Dez / 2015, p. 120.

27 Idem, p. 119. 
Assim, no contexto social e histórico do séc. XXI, o movimento de humanização e democratização da relação médico-paciente ganha impulso. A valorização da dignidade da pessoa humana e a defesa de sua autodeterminação leva reconhecimento da autonomia do enfermo e, por conseguinte, a ideia de que ele é quem deve decidir o é melhor para $\mathrm{si}^{28}$.

\subsection{O RESPEITO A AUTONOMIA DA VONTADE DO PACIENTE}

A vontade é definida pelo dicionário Michaelis ${ }^{29}$ como a "faculdade de que dispõe o ser humano de querer, de optar e de fazer ou deixar de fazer determinados atos livremente, sem qualquer tipo de interferência”, por sua vez, a autonomia representa a “capacidade de autogovernar-se, de dirigir-se por suas próprias leis ou vontade própria; soberania". Tais conceitos ganharam papel de destaque no mundo jurídico com a ascensão da burguesia e seus ideais iluministas.

A Constituição da República, em seu artigo $5^{\circ}$, IV, VI e VIII assegura o denominado princípio da autodeterminação moral, garantidor da liberdade dos indivíduos pensarem e orientarem sua conduta da forma que lhes pareça apropriada, baseada em qualquer que seja a crença ou a convicção. Por sua vez, a Declaração Universal dos Direitos do Homem de 1948, de igual modo, assegura a liberdade de pensamento, consciência, religião, opinião e expressão.

Desse modo, as convicções de cada indivíduo devem ser levadas em consideração quando da análise da possibilidade de o indivíduo escolher os diversos tratamentos terapêuticos apresentados pelo médico. Este, como profissional responsável pelo tratamento da pessoa enferma, deve exercer seus deveres nos termos do ordenamento vigente, dentre elas o Código de Ética Médica (Resolução CFM nº 1.931/2009), contudo ele deverá respeitar a vontade e, consequentemente, as decisões que vierem a ser tomadas pelo paciente.

Da mesma forma, no campo da Bioética, a ciência que estuda a ética e a vida, e que se traduz num verdadeiro compromisso social do Direito e da Medicina, também se verifica o respeito à autonomia da vontade do paciente pelo médico, por meio de um dos

\footnotetext{
28 Ibidem, p. 120.

29 Dicionário Michaelis. Disponível em: < http://michaelis.uol.com.br/busca?id=aKzwL >. Acesso em 07 de abr. 2019.
} 
quatro grandes princípios éticos norteadores da experimentação com o corpo do homem (os outros princípios são o da beneficência, da não maleficência e o da justiça) .

O médico, portanto, deve respeitar a vontade do paciente, informando-lhe sobre seu diagnóstico bem como sobre as opções de tratamentos ou experimentações disponíveis. Com os devidos esclarecimentos dos riscos e das questões que envolvem seu corpo e sua vida o paciente poderá de maneira voluntária fornecer ao médico o livre consentimento informado. Tem-se, portanto, que "a exigência do consentimento informado sintetizou o respeito à autonomia do paciente, sendo amplamente reconhecido nos códigos de ética médica de vários países e, até mesmo, em legislações específicas"30.

Os deveres dos médicos podem ser sistematizados em três grandes grupos, quais sejam: i) os deveres de técnica e perícia; ii) os deveres de cuidado, diligência e prudência; e, por fim o que mais nos interessa, iii) os deveres de informação e esclarecimento ${ }^{31}$. Sucede que para o paciente manifeste sua vontade livre de vícios e, por conseguinte, um consentimento informado efetivo, o médico necessita cumprir o seu dever específico de prestar informação e esclarecimento.

Bruno Nubens Barbosa Miragem $^{32}$ sustenta que o dever de informação e esclarecimento tem por fundamento a boa-fé objetiva, a qual se apresenta como um dos efeitos dos deveres anexos à obrigação principal, dentre os quais pode-se destacar o dever de colaboração, lealdade e respeito às expectativas legítimas da outra parte.

Sucede que a relação médico-paciente não se resume a um simples contrato entre partes que ocupam horizontalmente o mesmo espaço de poder, em verdade, o paciente ao procurar um médico encontra-se muita das vezes necessitado de um diagnóstico ou um tratamento. Nessa situação o médico encontra-se em uma situação de poder em relação ao paciente que, via de regra, está com sua integridade psicofísica abalada e seus familiares encontram-se afetados com os riscos ocasionados pela doença. Tem-se, portanto, uma situação de vulnerabilidade agravada do paciente e de seus familiares ${ }^{33}$.

Nesse contexto de vulnerabilidade, a informação e o esclarecimento deverão ser prestados de modo a garantir um resultado final, ou seja, deverão tomar a forma

30 Matos G. Aspectos jurídicos e bioéticos do consentimento informado na prática médica. Rev Bioética [Internet]. 2007 [acesso em 2016 Mar. 21]; 15(2):196-213. Disponível em: <http://revistabioetica.cfm.org.br/index.php/revista_bioetica/article/view/41>. Acesso em $14 \mathrm{de}$ abr. 2019.

31 MIRAGEM, Bruno Nubens Barbosa. Responsabilidade civil médica no direito brasileiro. Revista de Direito do Consumidor. Vol. 63/2007, jul - set/2007, p. 52-91.

32 Ibidem, p. 54.

33 Ibidem, p. 55. 
necessária para que o público alvo, que em sua maioria é leigo, possa compreender os riscos e os aspectos principais que envolvem o tratamento, o procedimento ao qual será submetido, os efeitos colaterais, bem como, se for o caso, o custo financeiro que envolve o tratamento apresentado pelo médico. No caso de diagnóstico, envolverá informação acerca do seu real estado de saúde, bem como todos os sintomas e consequências que a doença pode causar.

Uma vez observadas tais diretrizes poderá o paciente poderá formar sua opinião de modo verdadeiramente livre, pois estará ciente de todas as vantagens e desvantagens que envolvem o tratamento terapêutico indicado pelo médico. $\mathrm{O}$ paciente poderá manifestar o seu consentimento informado.

\section{CONTORNOS PARA UMA EFETIVA PROTEÇÃO DA PESSOA COM DEFICIÊNCIA}

A maior transformação que o modelo social almeja é haja uma efetiva modificação da visão de mundo que a sociedade tem das pessoas com deficiência.

Assim, é no plano da efetividade que se encontra os maiores desafios para a pessoa com deficiência, pois só se pode almejar uma efetiva igualdade de oportunidades quando no seio da família, do trabalho, da vizinhança e em qualquer lugar que se esteja, seja ela vista como autossuficiente e capaz de proceder às decisões que lhes afetam. Trata-se de uma verdadeira dignidade da pessoa humana.

À luz da legalidade positivada, toda e qualquer pessoa com deficiência, independente do grau de discernimento apresentado, possui capacidade para manifestar sua vontade e, portanto, poderá determinar o seu tratamento terapêutico. A norma tutela o exercício da autonomia das pessoas com deficiência, todavia, por não incluir "salvaguardas", pode gerar a uma insuficiência de proteção e expor a pessoa com deficiência no caso concreto a situações de extrema vulnerabilidade.

Em vista disto, parte-se para uma análise conjunta do Estatuto da Pessoa com Deficiência e da Convenção de Nova York, a fim de que possa tecer contornos para uma efetiva promoção da autodeterminação das pessoas com deficiência sem que se retire a rede de proteção necessária para os que em razão de severo comprometimento mental não possam exprimir a sua vontade.

O Estatuto da Pessoa com deficiência promoveu mudanças significativas no Código Civil, com a finalidade de garantir a autonomia das pessoas com deficiência. A 
incapacidade absoluta em razão do estado de saúde foi retirada do ordenamento, restou apenas a incapacidade relativa para aqueles que, por causa transitória ou permanente, não puderem exprimir sua vontade.

Com o intuito de assegurar a autodeterminação às situações existenciais das pessoas com transtornos mentais e de comportamento, tenham elas capacidade plena ou relativa. Todavia, a Lei de inclusão deixa de assegurar mecanismos de tutela às pessoas que não conseguem exprimir vontade e tampouco compreendem o significado e as responsabilidades advindas do casamento, deixou-se uma porta aberta para que pessoas de má-fé obtenham vantagens financeiras.

É inegável que a pessoa com deficiência tem o direito de realizar as escolhas que interferem na sua vida. $\mathrm{O}$ que se questiona é o alcance dessa norma no caso concreto, pois, se é desarrazoado prever genericamente a impossibilidade do enfermo mental sem o necessário discernimento para os atos da vida civil escolher qual o tratamento que deve ser submetido, sem levar em consideração as especificações individuais, na mesma medida é descabido imaginar que no complexo universo das pessoas com transtornos mentais e de comportamento todas possuem aptidão para entender as escolhas de tratamento, bem como os benefícios e malefícios que eles podem ofertar, a fim de manifestar um efetivo consentimento informado.

Assim sendo, é no campo da manifestação de vontade que reside o cotejo entre a autonomia e proteção dos vulneráveis. As situações que envolvem a declaração de vontade podem se dar de três formas: i) ausência total de manifestação; ii) manifestação equivocada; iii) efetivo consentimento informado.

O efetivo consentimento informado é a situação mais desejável, pois o indivíduo pode compreender os riscos e os aspectos principais que envolvem o tratamento, o procedimento ao qual será submetido, os efeitos colaterais, bem como, se for o caso, o custo financeiro que envolve o tratamento apresentado pelo médico. Todavia, nem sempre isso é possível.

$\mathrm{Na}$ primeira hipótese descrita não existe nenhuma declaração de vontade e, portanto, resta prejudicada a observação por parte do profissional da saúde da manifestação de vontade do paciente. Dentro desse universo engloba-se aquelas pessoas com severos transtornos mentais ou de comportamento que a priori poderiam exprimir sua vontade, conforme garante o Estatuto, todavia, não o poderiam fazer no caso concreto, vez que lhes faltariam um requisito para a formação do consentimento informado: a manifestação da vontade. Acerca da vontade pode-se afirmar que: 
é certo que, uma vez existente a vontade, seus efeitos somente serão sentidos na medida em que houver sua manifestação, vale dizer, quando o agente efetivamente declará-la. A conjugação da vontade à manifestação constitui a realização jurídica da vontade, que se exterioriza por meio da declaração de vontade Desta sorte, é possível afirmar que a declaração de vontade é composta de um elemento interno, seu conteúdo ou a vontade propriamente dita, e um elemento externo, a forma ou a declaração propriamente dita ${ }^{34}$.

Procura-se tutelar aqueles que em razão da deficiência não conseguem falar, gesticular ou fazer qualquer tipo de sinal que possa expressar o seu querer. Ressalta-se que essa impossibilidade de manifestar vontade não decorrer exclusivamente da deficiência, pois pode ter origem diversa, tal como a pessoa que se encontra em coma. Leva-se em consideração a necessária declaração de vontade da pessoa e não a sua condição como deficiente, o que se coaduna com o espírito do modelo social que está materializado na Convenção e no Estatuto.

Nesses casos, o consentimento informado do paciente será substituído por aquele expresso por seus familiares. Em que pese existir previsão expressa no sentido de que os atos que dizem respeito as questões existenciais não podem ser objeto de curatela, conforme dispões o caput do art. 85 do Estatuto da Pessoa com Deficiência, não há outro mecanismo de tutela dessas pessoas. Desse modo, recorre-se à Convenção, que permite a utilização das salvaguardas, a fim de que se tenha uma efetiva proteção da pessoa com deficiência.

Em relação a segunda situação, tem-se que a declaração de vontade é requisito para se tratar de efetivo consentimento informado, entretanto, não se trata de qualquer manifestação de vontade, ela precisa ser consciente e ordenada pelo íntimo querer do agente que estará ciente das consequências do ato. No que tange as pessoas com deficiência, essa vontade deverá ser considerada individualmente, de modo que levará em conta as limitações psíquicas e físicas, assim como a aptidão para compreender esse ato que diz respeito a sua esfera personalíssima.

Em razão da presunção de capacidade das pessoas com deficiência, tem-se que a priori a declaração de vontade por ela emanada produzirá os efeitos desejáveis sem que se levante nenhum tipo de questionamento. Todavia, quando diante do relativamente incapaz que por causa transitória ou permanente, não puder exprimir sua vontade, tanto a Convenção quanto o Estatuto preveem mecanismos de "salvaguardas".

34 TEPEDINO, Gustavo; BAROZA, Heloisa Helena; MORAES; Maria Celina Bodin de. Código Civil interpretado conforme à Constituição da República. Vol. I. Op. cit., p. 215. 
A Convenção ${ }^{35}$, prevê a possibilidade de "salvaguardas" em relação a capacidade legal com a finalidade de prevenir possíveis abusos em desfavor da pessoa com deficiência, desse modo o ordenamento apenas em situações excepcionais autorizará a decretação de capacidade relativa. Nesse sentido leciona Heloisa Helena e Vitor Almeida: Enquanto a pessoa tiver competência para explicar sua vontade, seja por meio de adequações razoáveis, intérpretes (caso da língua dos sinais utilizada pelos surdos) ou de apoiadores, em princípio, não tem cabimento a incapacidade relativa ${ }^{36}$.

A vulnerabilidade é definida como qualidade ou estado do que é ou se encontra vulnerável. Essa posição de vulnerabilidade pode surgir de duas formas, a primeira delas é aquela combatida pelo modelo social, e reside na forma como determinado grupo minoritário, no caso os deficientes, é tratado por toda a sociedade. A segunda forma que ela pode se concretizar diz respeito a uma vulnerabilidade inerente a determinada pessoa, ao estado individual que ela apresenta. É nesse segundo caso que se encontra a vulnerabilidade que as salvaguardas procuram zelar, a fim de se garantir a justiça no caso concreto. A vulnerabilidade existe, mas não pode ser uma válvula de escape social para negar se direitos fundamentais, em verdade, é preciso agregar proteção e autonomia para se ter uma efetiva tutela da pessoa humana.

O Estatuto da Pessoa com Deficiência fez alterações no Código Civil brasileiro, dentre as quais destaca-se o art. 1.783- A, que insere o instrumento da tomada de decisão apoiada. Ele é um intermediário entre a plena autonomia e a curatela, o seu objetivo é prestar apoio àquelas pessoas com deficiência que necessitam de um suporte externo para o exercício de sua autonomia. Conforme leciona Heloisa Helena Barboza e Vitor Almeida, os apoiadores funcionam como coadjuvantes do processo de tomada de decisões a respeito das escolhas de vida da pessoa com deficiência, e não o contrário,

35 Art. 12. 4. Os Estados Partes assegurarão que todas as medidas relativas ao exercício da capacidade legal incluam salvaguardas apropriadas e efetivas para prevenir abusos, em conformidade com o direito internacional dos direitos humanos. Essas salvaguardas assegurarão que as medidas relativas ao exercício da capacidade legal respeitem os direitos, a vontade e as preferências da pessoa, sejam isentas de conflito de interesses e de influência indevida, sejam proporcionais e apropriadas às circunstâncias da pessoa, se apliquem pelo período mais curto possível e sejam submetidas à revisão regular por uma autoridade ou órgão judiciário competente, independente e imparcial. As salvaguardas serão proporcionais ao grau em que tais medidas afetarem os direitos e interesses da pessoa.

36 BARBOZA, Heloisa Helena, ALMEIDA, Vitor. A capacidade civil à luz do Estatuto da Pessoa com Deficiência. In: MENEZES, Joyciane Bezerra de Menezes (Coord.). Direito das pessoas com deficiência psíquica e intelectual nas relações privadas: convenção sobre os direitos da pessoa com deficiência e Lei brasileira de inclusão. Op. cit., p. 264. 
como na hipótese de curatela, quando se eclipsa a vontade da pessoa curatelada num verdadeiro processo de substituição ${ }^{37}$.

$\mathrm{Na}$ tomada de decisão apoiada a pessoa com deficiência elege pelo menos duas pessoas idôneas, com as quais mantenha vínculos e que gozem de sua confiança, para prestar-lhes apoio na tomada de decisão sobre atos da vida civil, fornecendo-lhes os elementos e informações necessários para que possa exercer sua capacidade, nos termos do caput do art. 1.783-A.

Trata-se de um processo de jurisdição voluntária promovido pela pessoa com deficiência, no qual constará os limites do apoio a ser oferecido e os compromissos dos apoiadores, inclusive o prazo de vigência do acordo. Ele será submetido à apreciação do magistrado que contará com a presença da equipe multidisciplinar e com a oitiva do Ministério Público, bem como ouvirá pessoalmente o requerente e as pessoas que lhe prestarão apoio, e só depois poderá decidir acerca do pedido de tomada de decisão apoiada. Com o intuito de assegurar a autonomia da pessoa apoiada, ela pode a qualquer tempo, solicitar o término de acordo firmado em processo de tomada de decisão apoiada. Também poderá o apoiador eximir-se do acordo de apoio, todavia, seu desligamento estará condicionado à manifestação do juiz sobre a matéria.

Este é o instrumento mais desejável a ser utilizado, sobretudo quando diante de pessoas que se encontram nesse "limbo" entre ausência total de manifestação de vontade e livre consentimento informado, à medida que mantem a decisão final nas mãos da pessoa com deficiência ao mesmo tempo que não a desamparada dentro do seu contexto de vulnerabilidade.

\section{CONSIDERAÇÕES FINAIS}

A mudança de paradigma estabelecida pela adoção do modelo social trouxe para o ordenamento jurídico pátrio, em especial para o Direito Civil, profundas mudanças no clássico instituto das incapacidades. Com a finalidade de tutelar a pessoa humana deficiente, passou-se a promover políticas legislativas com a finalidade de viabilizar a

37 BARBOZA, Heloisa Helena, ALMEIDA, Vitor. A capacidade civil à luz do Estatuto da Pessoa com Deficiência. In: MENEZES, Joyciane Bezerra de Menezes (Coord.). Direito das pessoas com deficiência psíquica e intelectual nas relações privadas: convenção sobre os direitos da pessoa com deficiência e Lei brasileira de inclusão. Op. cit., p. 269. 
autonomia, autodeterminação e igualdade, sobretudo no que tange as questões existenciais.

Neste cenário, a escolha do tratamento terapêutico que a pessoa com transtorno mental ou de comportamento se subordinará por meio do consentimento informado, é concebida como uma manifestação de autodeterminação, à medida que o paciente escolhe o que entende ser melhor para si e, em última análise, garante-se a dignidade humana da pessoa com deficiência. No entanto, há que se ressaltar que é preciso garantir mecanismos de salvaguarda, pois a pessoa com transtorno metal e de comportamento poderá apresentar no caso concreto vulnerabilidade.

A análise da declaração de vontade no ato de exprimir o consentimento informado deve levar em contas as limitações individuais, todavia, ela precisa estar presente para que ocorra a escolha do tratamento terapêutico que o paciente será submetido. Assim, a curatela subsiste nos casos em que o paciente não pode exprimir de nenhuma forma a sua vontade.

No que tange a tomada de decisão apoiada, ela poderá ser aplicada aos atos de cunho existencial, vez que não há restrição ao auxílio, bem como que não ocorre substituição da vontade do apoiado. Assim, o paciente que não tenha a plena capacidade de analisar dentre as opções terapêuticas apresentadas aquela que melhor se enquadra na sua realidade, poderá recorrer a esse mecanismo para expressar o seu efetivo consentimento informado.

\section{REFERÊNCIAS}

AZEVEDO, Gislaine Campos; SERIACOPI, Reinaldo. História: volume único. São Paulo: Ática, 2005.

BARBOZA, Heloisa Helena, ALMEIDA, Vitor. A capacidade civil à luz do Estatuto da Pessoa com Deficiência. In: MENEZES, Joyciane Bezerra de Menezes (Coord.).

Direito das pessoas com deficiência psíquica e intelectual nas relações privadas: convenção sobre os direitos da pessoa com deficiência e Lei brasileira de inclusão. Rio de Janeiro: Editora processo, 2016, p. 249-274.

Heloisa Helena; ALMEIDA JUNIOR, Vitor de Azevedo. A (in) capacidade da pessoa com deficiência mental ou intelectual e o regime das invalidades: primeiras reflexões. In: EHRHARDT JR., MARCOS (Coord.). Impactos do novo CPC e do EPD no Direito Civil brasileiro. Belo Horizonte: Fórum, 2016.

Heloisa Helena, ALMEIDA JUNIOR, Vitor de Azevedo. Reconhecimento, inclusão e autonomia da pessoa com deficiência: novos rumos na proteção dos vulneráveis. In: BARBOZA, Heloisa Helena, MENDONÇA, Bruna Lima de, 
ALMEIDA JUNIOR, Vitor de Azevedo (Coords.). O Código Civil e o Estatuto da Pessoa com Deficiência. Rio de Janeiro: Editora processo, 2017, p. 1-30.

BORGES, Gustavo. Responsabilidade civil por ausência de consentimento informado no atendimento médico: panorama jurisprudencial do STJ. Revista de direito privado. Vol. 64/2015, Out - Dez / 2015.

DEJONG, G. The movement for independent living: origins, ideology and implications for disability research, Michigan State University Press: East Lansing, 1979; SHAPIRO, J. No pity. People with disabilities for ging a new civil right movement, Times Books, New York: Random House, 1994 y GARCIA ALONSO, J. V. (coord.), El movimiento de vida independiente: Experiencias Internacionales, Madrid: Fundación Luis Vives, 2003.

Dicionário Michaelis. Disponível em: < http://michaelis.uol.com.br/busca?id=okKKG>. Acesso em 11 de mai. 2019.

FARIAS, Cristiano Chaves de; CUNHA, Rogério Sanches; PINTO, Ronaldo Batista. Estatuto da pessoa com deficiência comentado artigo por artigo. 2. ed. Salvador: JusPodivm, 2016.

GOMES, Júlio Cezar Meirelles. Erro médico: reflexões. Disponível em: <http://revistabioetica.cfm.org.br/indez.ph/revista_bioetica/article/viewArticle/459>. Acesso em 10 de mai. 2019.

Matos G. Aspectos jurídicos e bioéticos do consentimento informado na prática médica. Rev Bioética [Internet]. 2007 [acesso em 2016 Mar. 21]; 15(2):196-213. Disponível em: 〈http://revistabioetica.cfm.org.br/index.php/revista_bioetica/article/view/41>. Acesso em 14 de abr. 2019.

MENEZES, Joyciane Bezerra de Menezes. O novo instituto da tomada de decisão apoiada: instrumento de apoio ao exercício da capacidade civil da pessoa com deficiência instituído pelo Estatuto da pessoa com deficiência - Lei brasileira de inclusão (Lei no 13.146/2015). In: MENEZES, Joyciane Bezerra de Menezes (Coord.). Direito das pessoas com deficiência psíquica e intelectual nas relações privadas: convenção sobre os direitos da pessoa com deficiência e Lei brasileira de inclusão. Rio de Janeiro: Editora processo, 2016.

MIRAGEM, Bruno Nubens Barbosa. Responsabilidade civil médica no direito brasileiro. Revista de Direito do Consumidor. Vol. 63/2007, jul - set/2007.

MONTEIRO, Washington de Barros. Curso de Direito Civil: Parte Geral. 19. ed. São Paulo: Saraiva.

Ordenações Filipinas, vol. 4. Edição de Cândido Mendes de Almeida, Rio de Janeiro de 1870, p. 1004/1005. Disponível em:

<http://www1.ci.uc.pt/ihti/proj/filipinas/14p1004.htm>. Consulta em: 15 de ago. 2017.

PALACIOS, Augustina. El modelo social de discapacidad: orígenes, caracterización y plasmación en la Convención Internacional sobre los Derechos de las Personas con Discapacidad. Madrid: Cermi, 2008.

, Augustina; BARIFFI, Francisco. La discapacidad como uma cuestión

de derechos humanos: uma aproximación a la Convención iternacional sobre los derechos de las personas com discapacidad. Telefónica y Cermi. Madrid: Cinca. 
ROSENVALD, Nelson. A "caixa de pandora" da incapacidade absoluta. Disponível em: <https://www.nelsonrosenvald.info/single-post/2017/06/06/A-\%E2\%80\%9Ccaixade Pandora\%E2\%80\%9D-da-incapacidade-absoluta>. Consulta em: 13 nov. 2017.

Nelson. O modelo social de direitos humanos e a convenção sobre os direitos das pessoas com deficiência - o fundamento primordial da Lei $n^{\circ}$ 13.146/2015. In: MENEZES, Joyceane Bezerra de (Coord.). Direito das pessoas com deficiência psíquica e intelectual nas relações privadas: convenção sobre os direitos da pessoa com deficiência e Lei brasileira de inclusão. Rio de Janeiro: Editora processo, 2016.

TEPEDINO, Gustavo; BAROZA, Heloisa Helena; MORAES; Maria Celina Bodin de. Código Civil interpretado conforme à Constituição da República. Vol. I. 